\title{
Special issue on mechanisms of French contact influence in Middle English: diffusion and maintenance ${ }^{1}$
}

\author{
Edited by \\ OLGA TIMOFEEVA \\ University of Zurich \\ and \\ RICHARD INGHAM \\ University of Westminster
}

\section{Introduction}

Recent years have seen a spate of publications that attempt to recontextualise the history of English in contact-linguistic (Miller 2012; Lutz 2013; Durkin 2014) and sociolinguistic terms (Millar 2012), and conversely to confront previous descriptions of contact phenomena with new data and theoretical insights available from situations of language shift and substratum influence (Filppula, Klemola \& Paulasto 2008; Vennemann 2011), extensive bilingualism (Schendl \& Wright 2011), language acquisition (Ingham 2012) and contact-induced grammaticalisation (Timofeeva 2010). Coupled with advances in our understanding of contact- and acquisition-induced language change (Heine \& Kuteva 2005; Jarvis \& Pavlenko 2008), and of the role of contact in the varieties of English around the world (Schreier \& Hundt 2013), there is a clear need in this area of historical research for scholars to reinvestigate earlier stages of English as a contact language.

In no respect is the need greater than as regards contact between English and medieval French, with which the present special issue is concerned. This has a long tradition. Since Otto Jespersen's A History of Foreign Words in English (1905) many scholars have attempted to establish the scale of Romance loans in the Middle English period, track down their first attestations and categorise them into semantic domains (Serjeantson 1935; Käsmann 1961; Strang 1970; Dekeyser 1986; Coleman 1995). Others have been concerned with the penetration of French morphology into Middle English derivation (Dalton-Puffer 1996; Palmer 2009; Lloyd 2011; Gardner 2014) and with the extent of French influence on Middle English syntax and phraseology (Orr 1962; Visser 1963-73; Iglesias-Rabade 2003; Haeberli 2010; Trips 2014). None of

\footnotetext{
1 This special issue is based on workshop presentations at the International Conference of English Historical Linguistics in Essen, 22-26 August 2016 (ICEHL-19). We wish to thank the participants and audience of the workshop for fruitful discussions of language-contact phenomena. Our special thanks go to the contributors and reviewers of the volume for their research and criticism, commitment to deadlines and patience when working under time pressure.
} 
these linguistic points can be dealt with satisfactorily without a proper understanding of the nature of contact between English and Anglo-French ${ }^{2}$ in the period following the Norman Conquest and of its societal dimensions. Here, scholarly opinions have fluctuated considerably over the last forty years, from (i) limited bilingualism among the upper classes up to around 1200-50, resulting in a Middle English creole (Bailey \& Maroldt 1977), or a Middle English shift variety (Thomason \& Kaufman 1988), to (ii) functional bilingualism among the upper and middle classes (Short 1980, 2009), resulting in language mixing, especially, in some professional domains (Wright 1996, 2000, 2005; Ingham \& Marcus 2016). A brief review of earlier claims may explain why recent approaches have taken new directions. In standard textbook treatments, discussion of the social role of French seldom went beyond claims about aristocratic bilingualism and the high prestige of the source language (see such accounts as Hughes 2000). Thomason \& Kaufman (1988) offered an account of the place of English-French contact within a broader framework of contact linguistics, which has shaped scholarly perception of the problem for several decades. Minimising the competence of French users in later medieval England (see also Berndt 1972 and Lass 1987), they believed that ' $[\mathrm{t}]$ here is no reason to suppose that any large proportion of native English learned French between 1066 and 1250; after that point they had no reason to do so' (1988: 308). After the loss of Normandy in 1204, anti-French feelings were, supposedly, so strong that there was a conscious move among the elite to unlearn French: 'The rank of aristocracy began to speak mainly English ... and to forget how to speak French' (1988: 268). Although Thomason \& Kaufman acknowledged the growth of French loanwords, their social explanation of the change was essentially speculative: 'Around $1250, \ldots$ French loans began to pour into ME. This suggests that between 1200 and 1250 the Norman nobility to a great extent began learning English and interacting with monolingual English speakers' (1988: 269). No evidence was offered, however, that learning and interacting with English speakers had not previously occurred, and research showing that such interaction between the speaker communities had taken place extensively in the bilingual situation described by Short (1980) was not acknowledged. Thomason \& Kaufman put forward the curious notion that rapidly decreasing competence in French in the thirteenth century was accompanied by a profound impact on English vocabulary, saying: 'By the end of the thirteenth century the French being written in England was simply awful. By the early 1300 s there is good evidence that very few nobles spoke French very well, if at all. ${ }^{3}$... Medieval French loans into English ceased for all practical purposes by 1400' (1988: 269), etc., etc. Their attempt to envisage the process of contact in terms of language shift thus appears unsatisfactory on chronological grounds. More recent studies (Wright 1996, 2000; Short 2009; Wogan-Browne et al. 2009; Ingham 2012)

2 Also known as Anglo-Norman. The term 'Anglo-French' will be used here to refer to the variety of Old French used in England between the eleventh and early fifteenth centuries.

3 Similarly, over a decade later Hughes (2000: 122): 'Anglo-Norman was in essence a class dialect disseminated from London down the chain of authority.' 
have shown that the insistence on the eliteness of French and on its demise around 1250 looks dubious, once a substantial body of English, Anglo-French or multilingual texts from the period is taken into account. Such texts attest to the use of French in a wider range of social contexts than was traditionally acknowledged, and that, consequently, the sociolinguistic situation and the sociohistorical timeframe for French in post-1066 England should be substantially reconsidered.

Thanks to the work of Anglo-French specialists such as Rothwell (1993, 2001), Trotter (2003) and Short (2009), a better-substantiated account of insular French is now available. Publicly accessible websites such as the Anglo-Norman Online Hub textbase (Rothwell \& Trotter 2007), the Parliament Rolls of Medieval England (GivenWilson et al. 2005) and the Anglo-Norman Correspondence Corpus (Ingham 2008) show that in 1250 the use of Anglo-French as a vehicle for non-fictional written communication was about to bloom; far from declining into irrelevance as Thomason \& Kaufman believed, ${ }^{4}$ it was then that insular French came into its own (Hunt 2008). This being so, it becomes a great deal less surprising that peaks of French influence on the English lexicon are recorded from the mid thirteenth century onwards (Dekeyser 1986; Coleman 1995; Durkin 2014).

The contact situation in medieval England, and its consequences for English, can now be interpreted on the basis of a more accurate and empirically substantiated picture of the status of insular French than was available a generation ago. It has become clear that Anglo-French remained a functioning variety of French until the later fourteenth century (Rothwell 1993), indeed expanding its range of written-text functions after 1250. It was also a nonstandardised variety largely uninfluenced by the literary conventions of Old French, as shown by Trotter (2003), for whom attempts by some earlier commentators to portray it as a poorly mastered foreign language simply miss the mark. Legge (1980) even described Anglo-Norman as spoken French written down. It underwent a significant change of nature, evolving from an immigrant variety of western Old French in the eleventh and twelfth centuries, to a naturalistically acquired second language by approximately the thirteenth-fourteenth century. Furthermore, it was a spoken as well as a written variety, showing effects of pronunciation on written forms until a late stage (Kristol 1994) and register differences between speech-based and scriptural texts into the fourteenth century (Ingham 2016). It was widely used as a medium of communication among members of various nonaristocratic professional communities at least until the end of the fourteenth century (Ingham \& Marcus 2016). Finally, Anglo-French was the medium for a flourishing literary and religious culture (Wogan-Browne et al. 2009) and acted as a bridge to the cultural and technological life of the European continent (Trotter 2003). These findings suggest that French competence was not limited to the highest social classes but spread some way down the social scale.

\footnotetext{
${ }^{4}$ Most probably on the basis of Anglo-French literary production, which did indeed decline significantly from this point on.
} 
This body of earlier research has created conditions for further topics to be explored in the area of medieval English-French contact, which the present volume undertakes to address:

- diffusion of contact-induced influence across dialects, social strata, periods and subperiods of medieval English;

- social networks that promote innovation and diffusion of contact-induced change;

- the factors involved in competition between native and borrowed lexemes;

- maintenance of English lexis within select semantic domains and professional communities;

- language transfer and translation-induced contact effects.

The diffusion of contact influence has hitherto been considered only in terms of French influence spreading from aristocrats or royal bureaucrats and the like (Hughes 2000; Lusignan 2009). The problem that is not addressed, however, is that this would have involved aristocrats and bureaucrats speaking only to other French speakers. What is needed is to envisage a channel of communication through which bilingual speakers regularly communicated with the general mass of monolingual English speakers, and in so doing introduced French-origin terms, initially into the passive vocabulary of the latter, which could then become part of their active vocabulary too.

Given the strong link between the church (that produced most of our texts) and educational system (that produced all the clergy), on the one hand, and between the educational system and French competence (Ingham 2012), on the other, it seems inevitable to localise the most important milieu for the diffusion of contact-induced change within the numerous schooling communities in urban centres across the country. The vital link between the bilingual (and trilingual) clergy and the largely monolingual populace, from the first half of the thirteenth century, was strengthened by the spread of the friars. The new orders enjoyed exceptional geographical and social mobility and through their highly flexible preaching techniques were able to reach to the widest masses. These points are explored further in the articles by Ingham and Timofeeva.

Ingham's analysis of sampled data from the early fourteenth-century long poem Cursor Mundi demonstrates that some 70 per cent of the French loanwords attested in this text belong to the general word-stock of Middle English. In many instances they compete with and replace native-origin lexemes, as do such abstract nouns as age, folly, joy, poverty, etc. or such verbs as advise, blame, serve, visit, etc. The study suggests that they originate in the language practices of the bilingual clergy. This speech community was singularly placed not only to import French lexis into Middle English but also to facilitate its diffusion among ordinary monolingual laypeople during church observances, sermons and religious ministrations.

In her survey of the persistence and replacement of Old English religious terminology after 1066, Timofeeva similarly associates lexical innovation with 
bilingual communities of the medieval clergy. In their professional lexical domain, parish priests, monks and friars had a choice between the terminology inherited from the pre-Conquest period and a more 'international' Francophone lexis. Timofeeva observes that high-frequency Old English terms have a much better chance of survival into the Middle English and later periods, which may point at their wide diffusion outside the professional community. Low-frequency terms, on the other hand, have stronger connections with local traditions at individual monasteries and fail to resist the pressure of their French counterparts.

Another significant departure from traditional accounts of English-French contact is the onomasiological approach taken in all five lexical studies in this collection (Durkin, Ingham, Molencki, Sylvester and Timofeeva). Although it has long been acknowledged that under/after contact influence a reorganisation of lexical fields takes place, these tendencies are typically explored as happening at a pragmatic or stylistic level (e.g. Burnley 1992). In this collection, however, the agentivity of the recipient language appears more important. The authors explore not only borrowed lexemes themselves but also, and more importantly, the diachrony of their semantic fields, examining which words were used to express particular concepts across time, whether there was system-internal pressure to borrow into a particular underlexicalised subfield, what happens to the individual senses of a word when it is borrowed, and how the existing words (native or earlier loans) adjust semantically in relation to the new lexical item.

As mentioned earlier, insular French is typically identified in orthodox textbook treatments with the highest social strata, contrasted with English, the vox populi. Attention is then given to the importance of loanwords from aristocratic lifestyles such as chivalry, hunting and luxurious living. In fact, French influence penetrated much further, into ordinary occupations such as metalworking, building and woodworking: Ingham, Sylvester and Marcus (forthcoming) found that roughly a quarter of the domain-specific lexis here was of French origin. Even in more domestically based occupations, a similar proportion of the specialised vocabulary was found to have originated in French. The retention of a much larger portion of native English vocabulary in manufacturing domains shows that these various sectors never became the exclusive domain of monolingual Francophone artisans. Rather, bilingual speakers belonging to them were able to pass on their knowledge of French terms to their monolingual English-speaking counterparts. The speech communities of skilled workers seem therefore to provide a possible model of how French influence was diffused at this time. At a higher social level, the professional classes, whose proficiency in French is surveyed in Ingham \& Marcus (2016), the same mechanism of diffusion may be posited.

Sylvester's article in this volume continues this line of enquiry, investigating the domain of Building and the various levels of its semantic hierarchy where French loans are found. Her classification of lexical data includes the superordinate level, which contains native (e.g. English tool) and foreign (e.g. French instrument) terms in 
almost equal proportion, and the subordinate level, which is, in turn, subdivided into basic terms and hyponyms. At this level, there is a strong tendency to prefer native terms (including compounds) at the most technical end of the basic-hyponymic cline (e.g. board-axe 'axe used in splitting timber into boards'). Among the more basic terms, however, French loans are more readily accepted (e.g. English nail but also French tacket). Sylvester is cautious as to whether to interpret these findings as an attempt at precision in the most technical vocabulary or as a kind of national pride in the trade, hypothesizing that the conservative trends stem from within the speech communities of skilled, rather than lower-class, workers. The finding that the same professional community may promote the diffusion of loan lexis at the more basic level and disprefer loan lexis at the more technical level is surprising but not inconclusive, as, on the one hand, this points towards an interaction between the more peripheral members of this speech community with Francophone commissioners and middlemen and, on the other hand, towards a conservatism and self-identification with English terminology among the core community members. The dynamics of these two trends are explored in ongoing research based on the Bilingual Thesaurus of Everyday Life in Medieval England project.

Durkin's and Molencki's articles examine the nature of competition between French loanwords and native lexis, looking respectively at verbs and adjectives, rather than following the tendency in the history of English research literature to concentrate mainly on nouns when discussing lexical borrowing. Their case studies focus on instances where the loanword has become part of the basic vocabulary of English, partly or totally at the expense of Old English (near-)equivalents. They shed valuable light on diachronic onomasiology, an area described by Durkin (2014) as 'still in its infancy', which, it is hoped, these studies will help to stimulate further, especially given the resources now available, such as the Historical Thesaurus of the Oxford English Dictionary. Their articles show how relations between established and incoming lexemes can be explored so as to reveal factors in play, especially regarding the polysemy of the respective items.

With Haeberli's article, the focus shifts back to the ways in which French influence was diffused in Middle English, this time to the role of translations, which formed a large part of fourteenth-century Middle English prose works. Specifically, Haeberli considers the effect of French in maintaining the optional preverbal placement of object pronouns still observed in Middle English. His findings will raise interesting questions over the interpretation of the textual record as collected in corpora when taking the diachronic evolution of grammars as an object of study.

All these articles in one way or another contribute to the notion of Middle English as a layered entity composed of native and contact-influenced strata. The features of this language system, and the sociohistorical processes by which it came to assume the form it did, must be comprehended fully in order to appreciate the distinctiveness of Middle English and its place in the history of the language. 
Guest editors' addresses:

University of Zurich

English Department

Plattenstrasse 47

CH-8032 Zurich

Switzerland

olga.timofeeva@es.uzh.ch

Department of English, Linguistics and Cultural Studies

University of Westminster

32-38 Wells St

London W1T $3 U W$

$U K$

r.ingham@westminster.ac.uk

\section{References}

Bailey, Charles-James N. \& Karl Maroldt. 1977. The French lineage of English. In Jürgen M. Meisel (ed.), Langues en contact: Pidgins, creoles / Languages in contact, 21-53. Tübingen: Narr.

Berndt, Rolf. 1972. The period of the final decline of French in medieval England (14th and early 15th centuries). Zeitschrift für Anglistik und Amerikanistik 20, 341-69.

Burnley, David. 1992. Lexis and semantics. In Norman Blake (ed.), The Cambridge history of the English language, vol. II: 1066-1476, 409-99. Cambridge: Cambridge University Press.

Coleman, Julie. 1995. The chronology of French and Latin loan words in English. Transactions of the Philological Society 93(2), 95-124.

Dalton-Puffer, Christiane. 1996. The French influence on Middle English morphology: A corpus-based study of derivation. Berlin: Mouton de Gruyter.

Dekeyser, Xavier. 1986. Romance loans in Middle English: A reassessment. In Dieter Kastovsky \& Aleksander Szwedek (eds.), Linguistics across historical and geographical boundaries, vol. 1, 253-65. Berlin: Mouton de Gruyter.

Durkin, Philip. 2014. Borrowed words: A history of loanwords in English. Oxford: Oxford University Press.

Filppula, Markku, Juhani Klemola \& Heli Paulasto. 2008. English and Celtic in contact. New York: Routledge.

Gardner, Anne-Christine. 2014. Derivation in Middle English: Regional and text type variation (Mémoires de la Société Néophilologique de Helsinki XCII). Helsinki: Société Néophilologique.

Given-Wilson, Christopher, Paul Brand, Seymour Phillips, Mark Ormrod, Geoffrey Martin, Anne Curry \& Rosemary Horrox. 2005. The parliament rolls of medieval England, 1275-1504. Cambridge: Scholarly Editions.

Haeberli, Eric. 2010. Investigating Anglo-Norman influence on Late Middle English syntax. In Richard Ingham (ed.), The Anglo-Norman language and its contexts, 143-63. Woodbridge: York Medieval Press / Boydell \& Brewer.

Heine, Bernd \& Tania Kuteva. 2005. Language contact and grammatical change. Cambridge: Cambridge University Press.

Hughes, Geoffrey. 2000. A history of English words. Oxford: Blackwell. 
Hunt, Tony 2008. Anglo-Norman and the loss of Normandy. In Florence Bourgne,

Leo Carruthers \& Arlette Sancery (eds.), Un espace colonial et ses avatars, 141-52. Paris:

Presses de l'Université Paris-Sorbonne.

Iglesias-Rabade, Luis. 2003. French influence in Middle English phrasing: Some evidence

from at-prepositional phrases. Neuphilologische Mitteilungen 104, 281-301.

Ingham, Richard. 2008. Anglo-Norman Correspondence Corpus. Birmingham City University. http://wse1.webcorp.org.uk/anglo-norman/about.html

Ingham, Richard. 2012. The transmission of Anglo-Norman: Language history and language acquisition. Amsterdam: John Benjamins.

Ingham, Richard. 2016. Investigating language change using Anglo-Norman spoken and written register data. Linguistics 54(2), 381-409.

Ingham, Richard \& Imogen Marcus. 2016. Vernacular bilingualism in professional spaces, 1200 to 1400. In Albrecht Classen (ed.), Multilingualism in the Middle Ages and early modern age: Communication and miscommunication in the premodern world, 145-64. Berlin: De Gruyter,

Ingham, Richard, Louise Sylvester \& Imogen Marcus. Forthcoming. Penetration of French-origin lexis in Middle English occupational domains. In Michela Cennamo \& Claudia Barbirzio (eds.), Historical Linguistics 2015: Selected papers from the 22nd International Conference on Historical Linguistics, Naples, July 2015. Amsterdam: John Benjamins.

Jarvis, Scott \& Aneta Pavlenko. 2008. Crosslinguistic influence in language and cognition. New York: Routledge.

Jespersen, Otto. 1954 [1905]. Growth and structure of the English language, 9th edn. Oxford: Blackwell.

Käsmann, Hans. 1961. Studien zum kirchlichen Wortschatz des Mittelenglischen 1100-1350: Ein Beitrag zum Problem der Sprachmischung (Buchreihe der Anglia, Zeitschrift für englische Philologie 9). Tübingen: Niemeyer.

Kristol, Andres. 1994. La prononciation du français en Angleterre au XVe siècle. In Jacqueline Cerquiglini-Toulet \& Olivier Collet (eds.), Mélanges de philologie et de littérature médiévales offerts à Michel Burger, 67-87. Geneva: Droz.

Lass, Roger. 1987. The shape of English: Structure and history. London: Dent.

Legge, Maria-Domenica. 1980. Anglo-Norman as a spoken language. Anglo-Norman Studies 2, 108-17.

Lloyd, Cynthia. 2011. Semantic and word formation: The semantic development of five French suffixes in Middle English. Frankfurt am Main: Peter Lang.

Lusignan, Serge. 2009. French language in contact with English: Social context and linguistic change (mid-13th-14th centuries). In Wogan-Browne et al. (eds.), 19-30.

Lutz, Angelika. 2013. Language contact and prestige. Anglia 131(4), 562-90.

Millar, Robert McColl. 2012. English historical sociolinguistics. Edinburgh: Edinburgh University Press.

Miller, D. Gary. 2012. External influences on English: From its beginnings to the Renaissance. Oxford: Oxford University Press.

Orr, John. 1962. Old French and Modern English idiom. Oxford: Blackwell.

Palmer, Chris C. 2009. Borrowings, derivational morphology, and perceived productivity in English, 1300-1600. PhD dissertation, University of Michigan.

Rothwell, Andrew \& David Trotter. 2007. The Anglo-Norman Hub textbase. Aberystwyth University. www.anglo-norman.net

Rothwell, William. 1993. The 'Faus Franceis d'Angleterre': Later Anglo- Norman. In Ian Short (ed.), Anglo-Norman anniversary essays, 309-26. London: Anglo-Norman Text Society. 
Rothwell, William. 2001. English and French in England after 1362. English Studies 82, 539-59.

Schendl, Herbert \& Laura Wright (eds.). 2011. Code-switching in Early English. Berlin: De Gruyter Mouton.

Schreier, Daniel \& Marianne Hundt (eds.). 2013. English as a contact language. Cambridge: Cambridge University Press.

Serjeantson, Mary S. 1935. A history of foreign words in English. London: Kegan Paul.

Short, Ian. 1980. Bilingualism in Anglo-Norman England. Romance Philology 33, 467-79.

Short, Ian. 2009. L'Anglo-normand au siec̀le de Chaucer: Un regain de statistiques. In Claire Kappler \& Suzanne Thiolier-Méjean (eds.), Le plurilinguisme au Moyen Age, 67-77. Paris: L'Harmattan.

Strang, Barbara M. H. 1970. A history of English. London: Methuen.

Thomason, Sarah Grey \& Terrence Kaufman. 1988. Language contact, creolization, and genetic linguistics. Berkeley: University of California Press.

Timofeeva, Olga. 2010. Non-finite constructions in Old English, with special reference to syntactic borrowing from Latin (Mémoires de la Société Néophilologique de Helsinki LXXX). Helsinki: Société Néophilologique.

Trips, Carola. 2014. The position proper of the adjective in Middle English: A result of language contact. In Petra Sleeman, Freek Van de Velde \& Harry Perridon (eds.), Adjectives in Germanic and Romance, 73-93. Amsterdam: John Benjamins.

Trotter, David. 2003. Not as eccentric as it looks: Anglo-French and French French. Forum for Modern Language Studies 39, 427-38.

Vennemann, Theo. 2011. English as a contact language: Typology and comparison. Anglia 129, 217-57.

Visser, Frederick Th. 1963-73. An historical syntax of the English language. Leiden: Brill.

Wogan-Browne, Jocelyn, Carolyn Collette, Maryanne Kowaleski, Linne Mooney, Ad Putter \& David Trotter (eds.). 2009. Language and culture in medieval Britain: The French of England, c.1100 - c.1500. Woodbridge: Boydell \& Brewer.

Wright, Laura. 1996. Sources of London English: Medieval Thames vocabulary. Oxford: Clarendon Press.

Wright, Laura. 2000. Bills, accounts, inventories: Everyday trilingual activities in the business world of later medieval England. In David Trotter (ed.), Multilingualism in later medieval Britain, 149-56. Cambridge: Cambridge University Press.

Wright, Laura. 2005. Medieval mixed-language business texts and the rise of Standard English. In Janne Skaffari, Matti Peikola, Ruth Carroll, Risto Hiltunen \& Brita Wårvik (eds.), Opening windows on texts and discourses of the past, 381-99. Amsterdam: John Benjamins. 